\title{
The implementation of song lyric "I HAVE a DREAM by WESTLIFE" to improve students' vocabulary of verbs in the seventh grade students of MTsN Sidorejo Madiun
}

\author{
Ratna Dewi Wijayanti \\ Universitas PGRI Madiun, Indonesia \\ ratna@gmail.com
}

\begin{abstract}
English as an international language has important role in human life. The functions of learning English in Junior High School are; first, by studying English students are expected to have a means to develop their knowledge of science, technology and culture. The second is students are expected to be able to support the development of tourism. Students must be able to use a lot of vocabulary of English, if they want to be successfull in learning. Vocabulary is an important element in language besides pronunciation and grammar. We can't express ideas in English without learning English vocabulary.Based on the explanation above, the researcher is interested in conducting research titled " The Implementation Of Song Lyric "I Have A Dream By Westlife" To Improve Students' Vocabulary Of Verbs In The Seventh Grade Students Of MTsN SIDOREJO Tiron Madiun In The Schooling Year 2014/2015".Music and song are included in teaching media, the use of music and song in the classroom can stimulate very positive associations to someone who study language. The result of the analyzing data indicates that the uses of song lyric in teaching vocabulary of verbare divided into two steps. The first is preparation steps. The preparations steps includes prepare the material, stabling instructional purpose, prepares the lesson plan and syllabus. The second is learning process. The learning process includes pre-activity, whilst-activity, and post-activity.
\end{abstract}

Keywords: Song Lyric; Vocabulary

\section{INTRODUCTION}

English as an international language has important role in human life. People in this world use English in communicating with others, especially when they have to communicate with other people from difference countries. As a foreign language in Indonesia, english should be taught and given to the society especially to the students. English should be taught at schools either elementary, junior, senior and even university. Now, Indonesian people learn English because of the demand of the global era. They want to be able to communicate with other people fromother countries who have different language and culture.According to Gerhand in (Nuri, Erlik 2011:1) "English is studied by people who live in different place where it is not the first language of that people who live in". It means that English is used by people in the world as a second language. English language learners have to master language skills: listening, speaking, reading, and writing. It is supported by Bambang Yudi Cahyono (2010:ix), “When learning a language, people need to possess what native speakers or competent users of language possess, that is skills in listening, speaking, reading, and writing”. The functions of learning English in Junior High School are; first, by studying English students are expected to have a means to develop their knowledge of science, technology and culture. The second is students are expected to be able to support the development of tourism. Students must be able to use a lot of vocabulary of English, if they want to be successfull in learning. Vocabulary is an important element in language besides pronunciation and grammar. We can't not express ideas in English without learning English vocabulary. So that, when students are given a passage with word that are supposed to have been taught earlier, they still find it difficult to understand the meaning. To make students motivate and enjoyable to study vocabulary, the teacher should be creatively in delivering material. We should use variative strategies in teaching vocabulary. One of the strategies that can be 
used by teacher is using media to support the teaching learning process. There are some teaching media available now, so the writer uses song lyrics to improve students' vocabulary of verb.

The objective of the study is to find out the effectiveness does the use of song lyrics "I Have A Dream By Westlife" To Improve Students' Vocabulary Of Verbs In The Seventh Grade Students Of SMPN 1 Barat Magetan In The Schooling Year 2014/2015. The problems which are investigated in this study is: (1) How is the implementation ofusesong lyrics "I Have A Dream By Westlife" To Improve Students' Vocabulary Of Verbs In The Seventh Grade Students Of SMPN 1 Barat Magetan In The Schooling Year 2014/2015? (2) What are the advantages and disadvantages the use of song lyrics "I Have A Dream By Westlife" To Improve Students' Vocabulary Of Verbs In The Seventh Grade Students Of SMPN 1 Barat Magetan In The Schooling Year 2014/2015 ?. This study is aimed at finding out whetheris : (1) To describe the implementation of using song lyric "I Have A Dream By Westlife" to improve students vocabulary of verbs in the seventh grade students of SMPN 1 Barat Magetan in the schooling year 2014/2015. (2) To describe advantages and disadvantages of using of song lyrics "I Have A Dream By Westlife" To Improve Students' Vocabulary Of Verbs In The Seventh Grade Students Of SMPN 1 Barat Magetan In The Schooling Year 2014/2015?

\section{METHOD}

In research methodology, the researcher gives the explanation about the scientific way or effort to get the data by certain purposes and benefit. Research is an organized and systematic way of finding answer to question. In other words, research is an activity to, notice and formulate something and analyze until arranging the reports. According to Nunan (in Jordan,1997 :274), research is : "a systematic process of inquiry consisting of there elements or components (1) a question, problem or hypothesis (2) data and (3) analysis and interpretation of data". It means that, in research process the researcher does the study can be conducted in order to obtain data, eveidence, etc, which way support one approach or suggest solution. A.The place of the research The place of the research is the main limitation of research. Sukardi (2007:53) says that the place of research is a place where is the process of study that is used to get the problem solution when the research is done, it means that place of research is the location to study of problem solving in a research perfomance. Time of the research,the researcher conduct this research from September to February, 2015.

\section{FINDING AND DISCUSSION}

\section{FINDING}

After doing the research, the researcher has found some findings based on the data presentation. It is used to answer the problem in chapter 1. They are:

a) The implementation of the of song lyric to improve students' vocabulary of verb in the seventh grade students of MTsN Sidorejo Madiun years 2013/2014.

Based on the data presentation, the researcher presents the research findings as bellow: the researcher founds some data presented as follow:

\section{Pre-Activity}

Pre-activities were the opening step in teaching vocabulary of verb using Song Lyric. These activities were stated below:

a) Teacher opened the class by greeting the students and the students answered the teacher's greeting. 
b) Teacher asked the condition of students and the students responded that their conditions were fine.

c) Teacher checkedby calling their names one by one and students responded that there is one student who was absent.

d) Teacher asked the students about the material in last meeting and the students answered that last meeting they study about greeting.

e) The teacher reviewed again the last material before continue the next material.

f) The teacher arranged seating arranged that is productive and organized in the classroom. It made students have a clear understanding of what they studied.

g) Teacher introducedthe theme of learning and stated the purpose of teaching and learning would be learned and the students pay attention.

h) Teacher gave the students a short apperception about the learning theme by showing the video about song on whiteboard and the students imitated the song.

\section{Whilst-Activity}

Whilst activities or the main activities in teaching vocabulary of verbusing Song Lyric.

a) The teacher gave song about the english song. It is used to stimulate students' interest in the lesson.

b) The students paid attention the lesson.

c) The teacher explains about verb.

d) And then teacher gives paper of song lyric, and then he plays the song.

e) The teacher gave explanation about the example song.

f) The teacher gave worksheet to the students to on the whiteboard.

g) The teacher asks the students to identify the vocabulary of verb of song lyric and asks one of students to write on the whiteboard.

h) The students had finished doing their work, the teacher collected it.

i) The teacher and students corrected the worksheet. The students paid attention and answered it.

\section{Post-Activity}

In the post-activity, teacher closes the study by the following activities:

a) Teacher asked the students' difficulties and the students' state their difficulties.

b) The teacher answered the students' difficulties.

c) Teacher asked feedback to the students and many students state their opinion related the material.

d) Teacher reviewed and gave conclusion about the material given.

e) Teacher gave evaluation to do test and then the students do the test.

f) Teacher say good bye to the students.

g) Students gave response.

b) The advantages and disadvantages the use of song lyric to improve students' vocabulary of verb in the seventh grade students of MTsN Sidorejo Madiun in Schooling years 2013/2014.

As a teaching media, song prevents students' boredom in language classroom. The use of song in teaching learning process has good implication, those are:

1) Create a welcoming atmosphere. It is the function of songas a warmer, students are expected to be enthusiastic in thelearning process.

2) Facilitate a positive learning mood and motivate students tolearning. Music helps students to focus on the material discussedand raise their concentration in the learning activities.

3) Connect students to content topics. Students are expected tounderstand the topic that they studied through song lyrics. 


\section{DISCUSSION}

Based on the result of the observation, the researcher concludes that the implementation of song lyric to improve students' vocabulary of verb are suitable for learning process. There are two activities in learning process, such as the teachers' activities and students' activities. In learning process, the students are enthusiastic and interesting to follow the lesson. The procedures of the implementation use song lyric to improve students' vocabulary of verb are done into several steps. The teacher prepares the material include song that will be used as media to give students song lyric in paper, then teacher played the songs and asked students to listen it, and then teacher asked the students to find the vocabulary of verb in song lyric. The teacher determines the instructional purpose of song lyric to teach vocabulary of verb to make students understand especially in teaching vocabulary. The teacher prepares RPP and syllabus to teach the instructional, rules, goal, and not out of context from the materials. In teaching learning process, the teacher uses three steps. They are preactivities, whilst-activities, and post-activities.

After greeting, the teacher checks the students' attendance list. By saying "Students now, I will check the attendance list, I call your name and raise your hand. ... Thanks that all". The students answer and give response. Then, the teacher reviews the last meeting. Next, the teacher prepares song related with theme of the lesson that will be taught is vocabulary. The teacher gives questions to get students respond with listen the song to mention lyric and the students answered it. This step can make the students get motivation in teaching learning process. The teacher gave worksheet to the students to on the whiteboard, the song lyric as media to make teaching and learning process more interesting. The students must focus and be careful when the clues read. After that, the students developed in simple song they chose, the students discussed with other students. The students had finished doing their work, the teacher collected it. The last, the teacher and students corrected the work. The students pay attention and answer it. In the post-activity, teacher closes the study by the following activities: Teacher asked the students' difficulties and the students' state their difficulties. Teacher asked feedback to the students. Teacher reviewed and gave conclusion about the material given.

Song lyric is one of approaches that can be used in teaching learning process. By conducting song lyric as media, the problems will be solved because the students can learn happily and fun. But, there are some advantages of the use of song lyric to teach vocabulary of verb. As a teaching media, song prevents students' boredom in language classroom. The use of song in teaching learning process has good implication, those are:

Otherwise, the students are noisy in the classroom and their vocabulary is still low. The implementation of song lyric to improve students' vocabulary of verb make some students often noisy and the students' knowledge about English is still low. From the observation of the students, the researcher found other data that is suitable with this problem. The teaching learning process, some students are noisy and have limited vocabulary. The students are noisy in the class and they are confused when must answer the question at students' worksheet". It means that in the teaching learning process, the students are noisy. According the advantages and the disadvantages above, theresearcher concluded that the use of song in teaching learning processhas good effect than bad effect. It gives good effects to activateunderstanding and make students easy to memorize the material. 


\section{CONCLUSION}

The use of song lyric to teach vocabulary of verb at the seventh grade students of MTsN Sidorejo Tiron Madiun in Schooling years 2014/2015.They are as follows: (a) The planning of using song lyric to teach vocabulary of verb, before doing teaching learning process, the teacher makes the lesson plan (RPP) and syllabus to teach the material. In the implementation of song lyric to improve students' vocabulary of verb, the teacher uses three steps: pre-activities, whilst-activities and postactivities. (b) The implementation of song lyric to teach vocabulary of verb, the teacher starts the teaching learning process by giving greeting to the students, then the teacher shows thesong as media to make the teaching and learning process more be fun and interesting to the students. Then, the teacher gives explanation students can read and listen correctly. The last, the teacher gives worksheet and collects the worksheet. The advantages and disadvantages of using song lyric to improve students' vocabulary of verb in the seventh grade students MTsN Sidorejo Tiron Madiun in Schooling year 2014/2015. They are advantages follow :1)Create a welcoming atmosphere. It is the function of song as a warmer, students are expected to be enthusiastic in the learning process. (2) Facilitate a positive learning mood and motivate students to learning. Music helps students to focus on the material discussed and raise their concentration in the learning activities.(3) Connect students to content topics. Students are expected to understand the topic that they studied through song lyrics.(4) Reduce learning stress levels. As a filler, when students are boring teacher can stimulate them by playing music to make they active again.(5) Deepen understanding and reinforce memory through emotional association because songs are familiar with students live .So, students are easy to understand the material. The application of various kinds of teaching approach, technique, and method is to provide the students, especially with new approach to study interesting and students have high more enthusiasm. Teachers are suggested to use the approach and give motivation to the students so that the students can feel more confidence in studying the material.

\section{REFERENCES}

Arikunto, S. (2010). Prosedur Penelitian Suatu Pendekatan Praktek. Jakarta: PT.Rineka Cipta

Arsyad, A. (2010). Media Pembelajaran. Jakarta: PT.Raja Grapindo Persada.

Atiningsih, N., \& Styadi, E, W. (2011). Teaching English as a Foreign Language. Madiun: Istana

Brown, H. D. (2000). Principles of Language learning and Teaching: Fourth Edition. San Fransisco: Logman.

Brown, H. D. (2004). Language Assessment Principles and Classroom Practices. San Fracisco: Longman.

Cahyono, B.Y. (2009). TechiquesIn Teaching EFL Writing. Malang. State Universitas of Malang Press.

Cahyono, B.Y. (2010). The Teaching of English Language Skill and English Language. Malang: State Universitas of Malang Press.

Edge, J. (1991). Essentials of English Languange Teaching. London: Logman.

Gray, D. (2004). Doing Research in the Real World. London: Sage Publication.

Jarvis, P. (2006). The Theory and Practice of Teaching. London: Routledge.

Kothari, C.R. (2004). Research Methodology. India: New Age International.

Hiebert, Kamil. (2005). Teaching and Learning Vocabulary. London: L Elrbaum Associates.

Jeremy, H. (2001). How To Teach English. United Kingdom: Logman

Nunan, D. (2003). Practical English Language Teaching. The McGraw-hill. 
English Teaching Journal, Vol. 5 No. 1, Juni 2017

ISSN: 2338-2678

Sari, W. (2012). Qualitative Research Method: Theory and Practice. Jakarta Selatan: Salemba Empat.

Sugiyono. (2013). Metode PenelitianPendidikan Pendekatan Kuantitatif dan Kualitatif dan R\&D. Bandung: Alkabeta.

Smaldino and Russel. (2005). Intructional Technology and Media for Learning. London: Logman

Sukardi. (2007). Metodologi Penelitian Pendidikan. Jakarta: Bumi Aksara

Tarwiyah, S. (2008). Game, Song and Practical Ideas to Teach Language. Semarang

Thornbury, S. (2002). How To Teach Vocabulary. London: Biddles Ltd.

Yin, R .K. (2011). Qualitative Research From Start to Finish. New York: The Guilford Press. 